This is the final peer-reviewed accepted manuscript of:

Fauri, F. (2015). Italians in Africa (1870s-1914), or how to escape poverty and become a landowner. The international history review, 37(2), 324-341.

The final published version is available online at:

https://doi.org/10.1080/07075332.2014.904811

Rights / License:

The terms and conditions for the reuse of this version of the manuscript are specified in the publishing policy. For all terms of use and more information see the publisher's website.

This item was downloaded from IRIS Università di Bologna (https://cris.unibo.it/)

When citing, please refer to the published version. 


\title{
Italians in Africa (1870s-1914), or How to Escape Poverty and Become a Landowner
}

\author{
Francesca Fauri*
}

\begin{abstract}
From 1902 to 1907 Italian emigration to Africa reached its peak with an average of 12,770 emigrants per year. Egypt, Algeria, and Tunisia were the main countries of destination and immigration had grown from previous decades thanks to well established 'migration chains'. Information about opportunities and remittances from previous emigrants helped the poor siblings and friends left behind with their moves. Extremely poor Southern farmers and an uncommonly high proportion of females left for Africa in search for a job, better salaries, and the possibility of coming back to Italy with some savings. Sicily, Sardinia, Campania, and Calabria, and more specifically the cities of Syracuse, Cagliari, and Naples, were among the towns which developed the strongest links with Africa: emigrants were typically young farmers or fishermen, with limited formal schooling, who left on a temporary basis. Yet in Tunisia for instance, many settled with their families and bought a piece of land where they started cultivating grapes and producing wine. Others were artisans and carpenters, while many females emigrated from southern towns (as in the case of Catanzaro) as dressmakers or wet-nurses. This paper will look at the economic motives that pushed Italians to emigrate to Africa as well as what Africa offered them in terms of better living conditions and wages. Undoubtedly, for some years Africa represented a way out of a harsh life and hunger, which in the past had led either to a passive and fatalist acceptance of the situation, or to brigandage in the South.
\end{abstract}

Keywords: Italian emigrants; Africa; income differentials; Tunisia; land ownership

From 1902 to 1907 Italian emigration to Africa reached its peak with an average of 12,770 emigrants per year. Tunisia, Egypt, and Algeria were the main countries of destination and immigration had grown from previous decades thanks to well established 'migration chains'. Extremely poor southern farmers left for Africa in search of a job, better salaries, and the possibility of coming back to Italy with some savings. Sicily, Sardinia, Campania, and Calabria and more specifically the cities of Syracuse, Cagliari, and Naples, were among the regions and towns which developed the strongest links with Africa: emigrants were typically young farmers or fishermen, with limited formal schooling, who left on a temporary basis. Yet in Tunisia for instance, many settled with their families and bought a piece of land where they started cultivating grapes and producing wine. Others were artisans and carpenters, while many females emigrated from southern towns (as in the case of Catanzaro) as dressmakers, wet-nurses, and prostitutes (although the data for the latter category

*Department of Economics, University of Bologna Email: francesca.fauri@unibo.it. This work was supported by the European Union Jean Monnet Chair Grant No. 200488-LLP2011-IT-AJM-CH awarded to the author 
are unavailable and inferred only by contemporary writers' reports). This paper will look at the economic motives that pushed Italians to immigrate to Africa and what Africa offered them in terms of better living conditions and wages at the time. This paper will also concentrate on free migration movements and will not deal with the Fascist government-assisted or induced migration to the African empire. ${ }^{1}$

During Italy's mass-migration movement (1890-1914), Italians went to developed and less-developed countries all over the world. Income differentials were one of the basic push factors, yet historical, cultural, and geographical reasons made the Mediterranean African countries the natural destination shores of Italian labourers many decades before the Italian state was born (1861). The Mediterranean had not only witnessed warfare and strife, but also grew rich because of peaceful interrelations, a mutual exchange of goods, ideas, scientific knowledge, workers, and, to a lesser scale, professionals (engineers, doctors, accountants, and others). The Italian community in Egypt, Algeria, and Tunisia grew steadily and was the link with the post-unification immigration fluxes. ${ }^{2}$

Undoubtedly, for some years Africa represented an often temporary way out of a harsh life and hunger, which in the past had either led to a passive and fatalist acceptance of the situation or to brigandage in the south. Tunisia also offered the opportunity for a change in status from daily agricultural worker to small land-owner. Sicilians were quick to grab this chance: something completely out of reach in the archaic agrarian society from which they came.

This study to a large extent confirms the prevailing interpretation of Italian emigration, yet by focusing on the African case it sheds some new light on a different context, which attracted feeble fluxes in mass-migration years but testifies to the importance of long-term interconnections, as well as the ease of assimilation and cultural proximity of Mediterranean countries.

\section{The Italian economy at the end of the nineteenth century}

Italy is a latecomer to the world economic stage. Its catching-up process, although undeniably successful, started relatively late and was complicated by an increasing economic dualism. ${ }^{3}$ As a matter of fact, current research underlines the fact that regional indices of relative industrialisation as well as value added per worker in agriculture show only a modest North-South divide at the beginning of the new state in 1861. ${ }^{4}$ Therefore, it seems that the gap between the industrial triangle (Lombardy, Piedmont, and Liguria) and the Mezzogiorno was the result of changing current conditions and not of a path dependency present at unification. ${ }^{5}$ Undoubtedly, Italy's dualism swiftly worsened after unification because the North industrialised and took advantage of the evolution of the technology of production and organisation. By 1911 the per capita value added in the industrial triangle reached 662 lire against a Southern average of 361 lire. $^{6}$ The North's take-off inevitably left the South behind.

Giovanni Vecchi's new estimates of per capita GDP and life expectancy point in the same direction. A North-South divide was present but not huge at the level of per capita GDP in 1871, the poorest regions being Basilicata and Calabria, but Campania for instance was doing a bit better than Piedmont at the time $(2,247$ euro against 2,165 euro) and Sicily was just a little below the two regions (1,972 euro) (Table 1). Yet by 1911 the North-South income gap had doubled (from 607 euro to 1,474 euro). What happened in successive years was that the North improved faster; it developed and industrialised, offering better living conditions. The chance of living 
Table 1. Life expectancy and per capita GNP in Italian regions 1861-1911.

\begin{tabular}{|c|c|c|c|c|c|c|c|}
\hline & \multirow{2}{*}{$\begin{array}{l}1861 \\
\text { Life } \\
\text { exp. }\end{array}$} & \multicolumn{2}{|c|}{1871} & \multirow{2}{*}{$\begin{array}{l}1881 \\
\text { Life } \\
\text { exp. }\end{array}$} & \multirow{2}{*}{$\begin{array}{l}1901 \\
\text { Life } \\
\text { exp. }\end{array}$} & \multicolumn{2}{|c|}{1911} \\
\hline & & $\begin{array}{l}\text { Life } \\
\text { exp. }\end{array}$ & $\begin{array}{c}\text { Per capita } \\
\text { GNP }^{*}\end{array}$ & & & $\begin{array}{l}\text { Life } \\
\text { exp. }\end{array}$ & $\begin{array}{c}\text { Per capita } \\
\text { GNP }\end{array}$ \\
\hline Piedmont & 33.5 & 35.4 & 2,165 & 37.6 & 44.9 & 48.7 & 3,496 \\
\hline Lombardy & 31.5 & 32.4 & 2,324 & 35.6 & 42 & 44.9 & 3,618 \\
\hline Liguria & 36 & 37.2 & 2,909 & 37.6 & 45 & 48.2 & 4,664 \\
\hline Veneto & & 34.5 & 2,119 & 37.2 & 48.4 & 49.8 & 2,617 \\
\hline Lazio & & 27.8 & 3,066 & 32.4 & 43.4 & 47.5 & 4,524 \\
\hline Emilia-Romagna & 32 & 32.9 & 1,989 & 34.7 & 43.9 & 48.1 & 3,272 \\
\hline Tuscany & 32.1 & 33.4 & 2,201 & 34.2 & 40.8 & 42.6 & 2,954 \\
\hline Umbria & 34.7 & 36.4 & 2,081 & 37.1 & 44.7 & 48.8 & 2,799 \\
\hline Marche & 33 & 35.9 & 1,721 & 36.5 & 43.7 & 47.3 & 2,456 \\
\hline Campania & 29.5 & 31.2 & 2,247 & 34.4 & 40.8 & 43.7 & 2,857 \\
\hline Sicily & 34.4 & 32.1 & 1,972 & 35.8 & 40.8 & 42.3 & 2,581 \\
\hline Sardinia & 31 & 31.4 & 1,635 & 34.4 & 41.3 & 44.4 & 2,784 \\
\hline Abruzzi-Molise & 32.1 & 33.4 & 1,672 & 34.2 & 40.8 & 42.6 & 2,062 \\
\hline Apulia & 34.9 & 31.4 & 1,869 & 34.1 & 36.2 & 40.9 & 2,581 \\
\hline Basilicata & 28.5 & 27.6 & 1,402 & 31.3 & 36.8 & 41.9 & 2,226 \\
\hline Calabria & 31.2 & 31.9 & 1,450 & 33.7 & 42.1 & 45.2 & 2,126 \\
\hline
\end{tabular}

Note: * In euro.

Source: G. Vecchi, In ricchezza e in povertà (Bologna, 2010).

longer clearly improved in the Northern regions, while they improved at a much slower pace in the Southern regions, leaving Apulians last in life expectancy in 1911 (40.9 years).

Finally, data on the regional labour force employed in agriculture also show the expected (but not as big) North-South divide - 55.9\% against 61\% - with Southern regions, like Sicily, presenting a percentage of agricultural labour (53.9\%) lower than the Northern one. ${ }^{7}$ What happened in the following years was that this percentage stayed more or less at the same level for Sicily, while it fell considerably for the Northern regions (to $33 \%$ by 1938) mainly because the industrialisation process did not come about in the South and emigration remained for years the only alternative to underemployment and low-paid daily agricultural work. Only industrialisation offered more and better paid job opportunities and valid work alternatives to the fields. Where it did not occur, stagnation set in and emigration became an increasingly attractive possibility, as we will see below. In the words of Toniolo: 'As a rough guide one can say that for every worker who moved from agriculture to domestic industry in this period there were two who left Italy to work in the modern sector abroad. $^{8}$

What these new analyses tell us is mainly that Italy was overall a poor country at unification, that the interregional economic differences were present but mild, and that poor people from all over the country looked for a better life and working conditions abroad. The migration movement, which became a massive movement of people from the $1880 \mathrm{~s}$, affected all Italian regions with different intensities yet did not correlate to a North-South divide. However, Southern emigration increasingly 
soared, there being few alternatives to emigration. Growth was frustrated in the South because of long-term social and economic legacies which put overwhelming weight on successive development prospects. At the level of literacy, finance and credit facilities, public infrastructure, entrepreneurial skills, and land distribution and farming methods, as well as in diet and malnutrition, the South had been always behind. Half the population of Piedmont and Lombardy was already able to read and write at unification. In contrast, the literacy rate in the South was extremely low (from $12 \%$ to $20 \%$ of the population) and suffered from a very slow rate of improvement. In the regions of the Kingdom of the Two Sicilies, the literacy rate only increased to $40 \%$ by 1911 . The North was richer in social and human capital, which is one of the leading reasons for technological success. In order to create or adopt new technology inputs developed elsewhere and adapt them to local conditions, as the North was able to do, the population had to be educated and understand the importance of education. ${ }^{9}$

Furthermore, the road network in the South was very poor. Only $99 \mathrm{~km}$ of track had been put into use at unification, banking facilities were primitive and consisted mainly of grain banks (about 1,200) which lent seeds to peasant farmers on a barter basis, and industrial developments depended almost totally on the imported talent of foreign entrepreneurs. ${ }^{10}$ Latifundia still dominated the agricultural panorama in the South. Even with the abolition of feudalism, no substantial change had taken place in land ownership; the land remained in the hands of the aristocracy who relied above all on highly priced crops cultivated with ample supplies of cheap labour to raise the aggregate value of agricultural output. ${ }^{11}$ In general, Italian agriculture did not suffer from an inefficient use of resources, but of an excess of population relative to available resources: 'too many people chasing too little good land', due to a lack of compelling alternatives except emigration. ${ }^{12}$ This problem was exacerbated in the South where the workforce consisted mainly of day labourers who spent most of the year unemployed. ${ }^{13}$ The first available ISTAT (Istituto Nazionale di Statistica) data on daily agricultural income show a persistent North-South gap until 1912, when a convergence process seems on its way: also a result of the mass-migration movement (Figure 1).

Thus, given an average daily wage of 2.10 lire in 1911, Vera Zamagni has calculated that 280 days of work a year would have been necessary in order to guarantee an income above the subsistence level, solely in terms of food. However, 'we know that a day labourer never worked more than 180-200 days a year and this figure was often lower in heavily populated areas or in areas where there was extensive farming. ${ }^{14}$ If we add to this gloomy picture the fact that the food available in the South was completely of vegetable origin, leading to an unbalanced diet and widespread malnutrition, emigration increasingly appears as an alternative to hunger in the poorest Southern areas, even in $1911 .^{15}$

\section{Exit or voice}

With no possibility of achieving tolerable living conditions at home nor of changing things (protests - such as the Sicilian riots or moti - were suffocated at birth), many Italians chose to leave the country and thus were able to improve their standard of living. The majority of those who left Italy were young and illiterate and increasingly came from the peasantry. ${ }^{16}$ During the early days of emigration they were mainly from the North of Italy, but the 1880s saw a growing number of southerners leave the country. Italian emigration from 1876 until the First World War involved a 


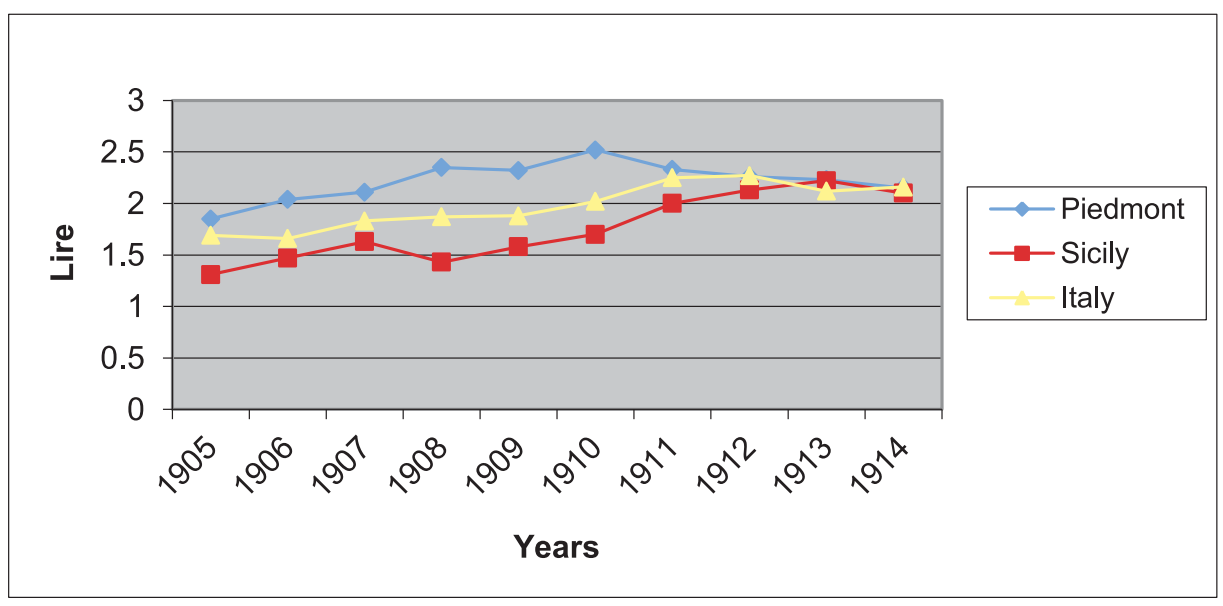

Figure 1. Agricultural income, 1905-14.

Source: ISTAT, I salari agricoli in Italia dal 1905 al 1933 (Rome, 1934).

movement of 13.5 million people, of which 5.3 million increasingly came from the Southern regions, including the islands. ${ }^{17}$

Italian emigrants started to prefer the Americas over Europe from 1886-7 onwards; in 1888 overseas emigration almost doubled in just one year. Among the explanations for this trend it must be remembered that in 1887 Italy introduced a new tariff and started a long and disruptive tariff war with France, which abruptly cut off Italy's raw silk and wine exports to its main export market. Furthermore, as a reaction to the falling price of imported grain in 1887 the government also raised the tariff on grain from 3 lire to 5 lire per quintal and finally to 7.50 lire in 1895 . At that point the duty increased the price of wheat on the domestic market by $50 \%$. Tariffs are barriers to trade but not to migration, which increased because of an improvement in transport costs and, according to Fenoaltea, because of the duty on grain, which 'was the greatest single cause of the Italian diaspora'. ${ }^{18}$ However, peasants and farmers traditionally consumed what they produced and the duty on grain cannot be considered the key determining factor for Italy's migration movement. What is beyond doubt is that in the 30 years before the war Italian emigration amazingly increased from 100,000 to 600,000 people a year. A very small but increasing percentage of this mass-migration movement (from $1 \%$ to $3 \%$ of the total) was directed towards Africa, as we shall see.

\section{Italian emigration to Africa: the push factors}

Given the widespread persistence of complementary emigration factors such as misery, malaria, short-sighted tariff policies, the lack of prospects for the future, and an immobile latifondist class in the South, the push factors for Italian emigration include four key fundamentals:

(i) A real wage gap between home and potential destinations (which is commonly considered the biggest emigration incentive). Hatton and Williamson have demonstrated how a $10 \%$ increase in the wage ratio increased 
the annual emigration rate by 0.7 per thousand. Hatton developed a model of the migration decision using a microeconomic framework in which potential migrants base their decision on the comparison of future expected incomes at home and abroad. ${ }^{19}$ Taylor and Williamson found that migration accounted for $70 \%$ of the convergence in wages between the old and the new world between 1870 and 1914 and that it increased real Italian wages by $28 \%{ }^{20}$ The wage gap between sending and receiving countries is undeniably a fundamental push factor and it also worked in the case of Italian emigration to Africa. The Sicilian day labourer earning from 1 lire to 1.5 lire per day knew he was going to earn at least twice as much if he were hired in construction work and even three to four times as much for a job in the mines.

(ii) Second, a high share of the labour force (redundantly) employed in agricul-

ture. As we have seen, in the Italian case the share of the labour force in agriculture was quite high for Northern and Southern regions alike at unification, ranging from $81 \%$ in Piedmont, $69 \%$ in Lombardy, and $62 \%$ in Liguria, to $73 \%$ in Basilicata, $62 \%$ in Campania and Calabria, and only $54 \%$ in Sicily. What is interesting is that by the time the migration movement started soaring at the turn of the century, the percentage of labour employed in agriculture decreased to $54 \%$ in the industrial triangle, while for the South (including the islands) it remained around 64\%. While in the North industrialisation set in, offering a compelling alternative to emigration, the lack of change and the absence of the conditions for growth in the South explain its immobility, it still being governed by a static agrarian society which left no other option but to exit in order to improve one's lot.

(iii) The third push factor relates to the demographic increase. Easterlin viewed the rate of natural population increase twenty years prior to any point in time a proxy for the rate of additions to the labour force. The increased labour force would result in a labour-market slackening and relatively higher migration. He argued that past demographic events had an indirect influence on present emigration through the home-labour supply. (Hatton and Willamson also found population increases raised the rate of emigration in the Nordic countries between 1885 and 1905). ${ }^{21}$ A correlation has been performed between Italian migrants and the population growth rate given a twenty-year lag. The correlation is positive and quite strong $\left(\mathrm{R}^{2}=0.3455\right)$ suggesting that a share of additional births in Italy ultimately spilled over into emigration. $^{22}$

(iv) The chain effect. The Mediterranean North African countries had developed strong interrelated links with Southern Italy over the centuries thanks to geographical proximity and the rather free circulation of goods and men. These long-established migrant communities generated new influxes, created a geographical continuity, developed migrant networks and often found jobs for incoming migrants, making migration a reasonable 'investment for the future, the best way of investing one's skills and income, to secure personal and family economic prospects'. ${ }^{23}$ The number of previous emigrants increased subsequent emigration flows. According to Hatton and Williamson, for every 1,000 previous emigrants, twenty more were pulled abroad every year. ${ }^{24}$ 
In the case of Northern African destinations, we may add the fact that its proximity to the Sicilian coasts greatly eased the poverty trap: the very low cost of the boat passage allowed the poorest to leave, who in many cases chose Africa over the Americas for this very reason (see below). Moreover, in this case, technological improvements in the naval industry had limited effects on the trip to North Africa, since it was close and easy to reach even on small sailing boats (bilancelle). Six hours and an outlay of 5 lire sufficed for the journey from Palermo to Tunis. In the words of Foerster: 'Since this country (Tunisia) is so accessible and in its physical traits it has so much in common with the Mediterranean island we cannot be surprised that Italians should have come to it freely. 25

Given the enormous amount of research on the push factors today, it is not difficult to devise what could have been the incentives Italians had to leave their home country. Yet, at the end of the 1870 s, when it became evident that the outflow of migrants was not going to cease, it had reached a level of more than 100,000 people leaving each year and was steadily increasing, the government started to worry and ordered the Ministry of Foreign Affairs to undertake a survey to collect information on the possible causes of emigration. Three lines of questioning were asked of the Prefects who had to fill out a report stating whether it was poverty and hunger that pushed people out of the country, whether it was an increase in the annual land rent, or whether it was the pressure from emigration agents sent by a few countries of immigration (mainly Brazil and Argentina). Secondarily, the Ministry wanted to know if it were true that male emigration outside Europe was most often followed by the wife and children of the emigrant - leading to permanent emigration as it was called - compared to a more temporary emigration directed to the closer European destinations. Finally, the Prefects had to find out whether emigration had a positive direct effect on local salaries, land values, and the overall agricultural economy. I have only considered the answers from the cities that saw a significant number of their citizens leaving for Africa. The Prefect of Naples was convinced that it was not so much desperation that forced people to leave, but the desire to share in the richness of those who had already conveniently settled abroad and the possibilities of working and earning good money in foreign and wealthier lands. The poorest farmers, he said, chose Africa and Egypt in particular because of the low cost of the journey. As for Catanzaro, it was the lack of job opportunities and the desire to earn higher salaries abroad, compared to the miserable local wage level, which pushed farmers to leave. Even in 1881 only a few left for America, while the majority embarked for Alexandria in Egypt where many women moved as wet-nurses (lured by very good remuneration) and probably prostitutes (although data for the latter category are unavailable and inferred only by contemporary writers' reports). Similarly, in 1881 the town of Reggio Calabria experienced a very low migration flow which was mainly directed to Alexandria. The women from the little Commune of Bagnara were well known to immigrate to Egypt as dress-makers. ${ }^{26}$ Thus, Africa was chosen because it was close, it was a low-cost trip, it offered better paid job opportunities, and the migration chains established in past (in a few cases before unification) apparently worked very well as emigration agents, advising when job opportunities opened (and closed).

The propensity of Italy's regional immigration to Africa changed over time. As illustrated in Table 2, during the thirty peak years of Italian emigration (1881-1911), Africa gained and lost importance according to the region of origin. The number of emigrants from Campania only slightly decreased over time, while 
Table 2. Italian emigrants to Africa per main sending region $(1881-1911)^{*}$.

\begin{tabular}{lccc}
\hline & $\mathbf{1 8 8 1}$ & $\mathbf{1 9 0 1}$ & $\mathbf{1 9 1 1}$ \\
\hline Sicily & 273 & 3,618 & 2,314 \\
Sardinia & 60 & 1,841 & 828 \\
Campania & 802 & 582 & 724 \\
Piedmont & 123 & 214 & 562 \\
Tuscany & 339 & 947 & 555 \\
Veneto & 52 & 28 & 504 \\
Apulia & 43 & 603 & 457 \\
Emilia & 265 & 300 & 361 \\
Calabria & 608 & 891 & 325 \\
Lazio & 0 & 55 & 216 \\
Lombardy & 137 & 106 & 184 \\
Liguria & 28 & 17 & 162 \\
Marches & 21 & 61 & 94 \\
Abruzzi and Molise & 33 & 130 & 61 \\
Basilicata & 7 & 91 & 28 \\
Umbria & 1 & 15 & 18 \\
Total & $\mathbf{2 , 7 9 2}$ & $\mathbf{9 , 4 9 9}$ & $\mathbf{7 , 3 9 3}$ \\
\hline Note: & & &
\end{tabular}

Note: ${ }^{*}$ In 1901 they represented $1.8 \%$ of Italian emigration.

Sources: MAIC, Statistica dell'emigrazione italiana per l'estero anno 1881 (Rome, 1882); MAIC, Statistica della emigrazione italiana per l'estero con una appendice di confronti internazionali (Rome, 1913).

the number from Calabria, Apulia, Sicily, and Sardinia, after reaching the highest level at the end of the century, rapidly slowed down in successive years due to the progressive and unbeatable competition from Southern and mostly North American destinations.

However, despite many Sicilians starting to move in great numbers to the US by the end of the century, a few never abandoned the African route completely; for some cities in particular, it remained the favourite continent of emigration until the First World War. The cities of Syracuse, Trapani, and Cagliari show a clear propensity to move to Tunisia, which grows steadily over time as the main African destination country, already outdoing Egypt in the last decade of the nineteenth century and representing a possible alternative to overseas emigration for many Sicilian farmers coming from Syracuse and Trapani in particular. The peak for Syracuse is reached in 1901 when 1,398 emigrants left for Tunisia. In the case of Sardinia, Cagliari is a case in point: no outward migration towards North or South America but a constant preference for the near Mediterranean sea towns (1,565 moved to Africa in 1901) where their fishing capacities were promptly exported and granted proper reward (together with their expertise in mines and forestry). ${ }^{27}$

\section{The main receiving African countries}

For historical, cultural, and geographical reasons, three countries in Africa most attracted Italian emigrants, with various degrees of intensity throughout the years. Algeria, Egypt, and Tunisia absorbed 170,000 out of 191,000 Italians who moved to Africa from 1876 to 1911 . As a matter of fact, these data do not capture the whole 


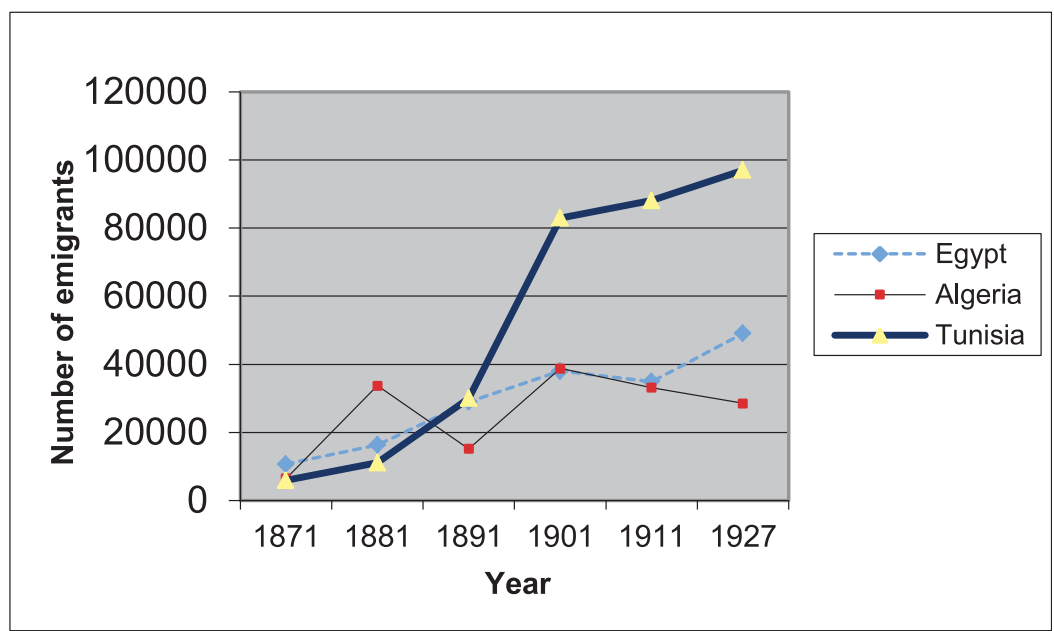

Figure 2. Italians living in Egypt, Algeria, and Tunisia, 1871-1927.

Source: MAE, Censimenti degli italiani all'estero, various issues.

extent of the migration movement to Africa, since, as reported by the Italian consulates in Africa, many emigrants from the South left the Italian coasts without a passport on small private sailing boats and their entry was never recorded. Thus, the amounts shown by ISTAT probably underestimate the phenomenon.

The data only show gross migration, and do not take account of any returns. Thus a more trustworthy picture of the Italian presence in Northern Africa can be inferred by the number of Italians living in Africa according to Italian census data. As shown in Figure 2, they increased the most in the case of Tunisia, which shows the steady growth of Italian residents from 1871 to 1927, a path followed by Egypt too, albeit at a slower pace. Algeria, on the other hand, shows a more stable presence of Italian migrants, whose community, except for the fall of 1891, stabilised at around 30,000 individuals. But why were Italians attracted to the African Mediterranean countries in particular? The answers can be found in the history of the relations with Italy of each of these three countries, which will be considered below. In economic terms they are: low-cost tickets; a reasonable distance from Southern ports; more and better paid job opportunities in various sectors (surely the onset of substantial public works was a key factor in all three cases); and last but not least, the concrete possibility of becoming small land-owners.

In 1871 Egypt was the African country with the greatest number of Italians, who were preceded only by the Greeks as foreign residents and followed by the French. The heyday of Italian emigration to Egypt developed under the governments of Said and Ismail Pascià. Italian traders, engineers, professionals in general (doctors in particular) and an increasing share of the labour force took part in the incessant growth of this African country, which attracted an increasing amount of Italian labour given the generous financing of a great number of public works. They worked as masons or stonecutters in the construction of the Suez Canal, as canal makers, helped to build the barrage across the Nile, and open weir half a mile long (1888-1902). They also worked at the Assuam Dam, on the bridges across the Nile at Kafr-el-Zaiat and Behna, the latter part of the railway route from Cairo to Alexandria. ${ }^{28}$ 
Table 3. Italian institutions in Mediterranean Africa in 1927.

\begin{tabular}{lccc}
\hline & Algeria & Egypt & Tunisia \\
\hline Public primary schools & 3 & 10 & 17 \\
Private primary schools & 3 & 5 & 19 \\
Public secondary schools & & 3 & 3 \\
Private secondary schools & 2 & \\
Hospitals & & 240 & 120 \\
Beds & & 4 & 4 \\
Colleges & 2 & 27 & 25 \\
Mutuo soccorso (mutual help) & 2 & 11 & 6 \\
Institutions for the diffusion of Italian culture & 1 & 1 & 2 \\
Economic associations & & 8 & 4 \\
Sport & 3 & 4 & 2 \\
Various & 1 & 6 \\
Newspapers and magazines & & 4 & 6 \\
\hline
\end{tabular}

Source: Author's elaboration from MAE, Censimento degli italiani all' estero alla metà del 1927 (Rome, 1928), 368-9.

Under Ismail Pasha (1863 onwards) Cairo was rebuilt in imitation of Paris; he also opened the Opera theatre, built railways, a telegraph network, a road system, irrigation canals, and operated factories. Immigration from Italy soared and schools and Italian institutions were set up (Table 3). Unfortunately Ismail used foreign money to finance such efforts. The Egyptian national debt more than quadrupled, loans were used to pay interest on earlier loans, and the fiscal system became a system of arbitrary tribute and confiscation. ${ }^{29}$ With the onset of the financial crisis, theatres were shut and Cairo became squalid and empty. Many Italians repatriated with what they were able to save from disaster. A much smaller number of Italians went back to the fertile Egyptian lands when order was restored as the UK took control of the country in 1882. Yet, little by little Egypt ceased to represent an attractive land to settle in abroad.

In the case of Algeria, Italian emigrants came mostly from the Southern provinces and settled in the Northern coast of Algeria: in Costantina, Philippeville, Bona, and La Calle. In the latter town, out of a population of 4,000 in 1881, 2,500 were Italians. Most went to Algeria on small sailing boats for a few lire, as a result of information about job opportunities sent by relatives or friends. Since 1879 a monthly steamship carrying on average 100 passengers each way connected Naples to the Algerian ports. Italian emigrants to Algeria were mainly fishermen (especially for coral, for which they were very much asked and well paid on French ships), agricultural daily workers, shoemakers, mine workers, marble workers, brick makers, plasters, and masons, who were often attracted and engaged in public works. ${ }^{30}$

However, foreigners were fiscally discriminated against and in 1878 the French colonial government passed statutory restrictions on the allotment of farms to those other than the French, thus contributing to the decline of Italian immigration. What the French attempted in every way was to favour their becoming French citizens and, as the Italian consul reports in 1881: 'Applications on the part of Italians have been multiplying lately since they get important fiscal advantages (no more special taxes on foreigners) and they can avoid draft. ${ }^{31}$ After the turn of the century, the 
Italian community in Algeria remained more or less stable at around 30,000 people, with sudden drops in the number of workers due to the lack of job opportunities.

The presence of an important Italian community in these countries brought with it the opening of Italian institutions, such as primary and secondary schools: fiftyeight in Egypt, forty-nine in Tunisia and three in Algeria, two hospitals in Egypt and one in Tunisia (Table 3).

\section{IV.i. The case of Tunisia: 'an Italian colony guarded by French soldiers'}

The case of Tunisia needs a more thoroughly analysis. In 500 and 600 the most commonly spoken foreign language in Tunisia was Italian. ${ }^{32}$ Well-developed trade relations with Pisa, Venice, Genoa, and Trapani, as well as the closeness of the Tunisian and Southern Italian coasts stimulated a growing Mediterranean link between the two countries. In 1700 Italian emigration to Tunisia started to increase when a group of well-educated Italian Jews from Livorno settled in Tunis. ${ }^{33}$ Most of them were merchants who made use of the links to Mediterranean commercial networks to assume important roles in Tunis, as agents for the corsairs and their financial backers. Their contacts and wealth enabled them to join the circle of the ruling elite, where they served as advisors, business representatives, or physicians to several beys. ${ }^{34}$ They developed thriving trade relations with Tuscany and Sardinia, to which cereals and oil were exported in great quantities. Free-trade commercial agreements were stipulated with the Sicilian government from 1833 and the shipping company Raffaele Rubattino set up a new bi-monthly maritime connection between Cagliari and Tunis in 1852, further stimulating emigration from Sardinia towards Tunisia and slowly diverting the usual flow towards Algeria. ${ }^{35}$ In 1860 Italy secured permission for its citizens to buy land in Tunisia and eight years later signed a treaty of friendship, commerce, and navigation with the Bey of Tunis. It was Prime Minister Menabrea who, in order to protect the growing Italian community, negotiated and signed a treaty on 8 September 1868, granting Italian settlers the opportunity to set up firms and buy land. As De Leone underlines: 'In a few years Italian agricultural communities multiplied and became prosperous. ${ }^{36}$ In 1870 a weekly connection from Palermo and Tunis started to operate: for 2 francs on a small sailing boat (bilancelle) and 5 francs on a steamer, Sicilians could reach Tunis overnight. ${ }^{37}$

By all accounts, the Italians appeared to be ready to conquer Tunisia in the 1860s; they even claimed that Emperor Napoleon III had sanctioned the move, but that English opposition delayed the plans. ${ }^{38}$ In the meantime, France continued its economic and financial penetration: it granted important loans to the African country in the 1860 s, it was allowed permission to build railroads (in the late 1870 s it completed construction of the railroad from the city of Tunis to the Algerian border), and was given mining and agricultural concessions. ${ }^{39}$ In addition, France arranged a shipping company to run weekly steamers between Marseille and Tunis and from Tunis to Tripoli and Malta, took control of the telegraph, and established a Banque du Crédit. In successive years the French government made it clear that Italy could not entertain ideas of conquest in Tunisia without risking a conflict with France. At the Congress of Berlin (1878) Salisbury and Bismarck offered Tunisia to France in order to keep her busy on other fronts and avoid retaliatory actions. ${ }^{40}$ Three years later France established its protectorate over Tunisia. In large measure France invaded Tunisia in 1881 to protect its economic interests and take advantage of the promising opportunities for French private investments. However, the origin of the 
French expedition in Tunisia must also in part be attributed to the growing Italian presence in the country and the concern about possible Italian political and economic advantage in Tunisia. ${ }^{41}$ At the time there were 20,000 Europeans in Tunisia, only 500 of whom were French, while 11,000 were Italian. Italy bitterly repented its immobility in Tunisia, deeply believing that: 'If there had ever been a country destined to settle in Tunisia, that was Italy. ${ }^{42}$ The Italian Prime Minister Francesco Crispi described Tunisia as 'an Italian colony occupied by France'. ${ }^{43}$ After the French occupation many Italian interests were taken over by the French, yet a substantial inflow of Italian labour started since, it was well known, 'where work was Italians went' ${ }^{44}$

\section{The Sicilians in Tunisia ('came like ants')}

French occupation opened the way for road, maritime, and railroad construction works and many Sicilians were attracted as masons and daily workers. Italians often immigrated to Tunisia on a temporary basis. In 1881 temporary Italian emigrants to Tunisia were usually employed by French rail construction companies on the Algerian border with the task of laying the railways, but they were also hired for building barracks, schools, hospitals, and prisons, as well as enlarging and deepening the ports of Tunis, Susa, Sfax and fortifying Bizerta. Indeed, Italians worked in many different fields including the phosphate mines. They usually repatriated when the works were over.

A more permanent form of emigration was composed of farmers coming from Sicily and the island of Pantelleria: a well-integrated group speaking the same language (dialect) and with the same cultural background. Trade with Sicily was well developed and carried forward by small sailing boats which connected Trapani with La Goletta daily. In the words of the Italian Consul in Tunis: 'Sicilian peasants are not influenced by emigration agents to move to Tunisia since they are certain of finding a second homeland in Tunis and increased material wellbeing. ${ }^{45}$ According to French contemporary observers: 'Sicily willingly offered its labour force ousted from their home country by hunger, malaria, heavy taxes and mafia' or 'Italians moved to Tunisia because their country, Sicily in particular, is overpopulated and the existing bad social and land organisation does not allow them to nourish their large families. ${ }^{46}$ The Italian population of Tunisia mushroomed, increasing by $88 \%$ during the first decade of the protectorate and it outnumbered French citizens by a ratio of five to one by $1896 .{ }^{47}$ In the first years of the new century, Sicilians reached 60,000 out of a foreign population of $80,000 .{ }^{48}$ As the Sicilian agricultural community increased, more peasants were attracted from the same area also on a temporary basis.

In 1905 a daily agricultural worker in Sicily earned about 1 franc. If he moved to Tunisia to do a temporary specialised agricultural job, such as planting a vineyard, or if he was an expert navvy, our Sicilian farmer would earn up to 4 francs a day, while ordinary unspecialised work in the fields was paid less, from 3 francs to 3.5 francs a day. French companies doing public works paid more, up to 4.5 francs and sometimes even 6 francs a day. Yet quite often when a French company won a contract in Tunisia, it would not look for labour on the spot, but rather would hire it in Sicily at a much lower cost - from 2 francs to 3.5 francs a day - for a few months. In the words of Loth (a professor at the University of Tunis at the time) Italians furnished a cheap but excellent, patient, and available labour force: 'No French mason would accept such harsh work for such a meagre salary. ${ }^{49}$ His testimony is also 
interesting because he tells us about the phenomenon of temporary immigration, well developed at the time but difficult to study from a quantitative point of view. In the new century the opportunity for temporary jobs increased in Tunisia and many Sicilian peasants moved there only for a couple of months, the necessary time to finish a specific task, as grape-harvesters or pruners. Similarly, 500-600 Sardinians disembarked on the Tunisian coast in May and went to work in the forests (where, for instance, they knew how to remove bark from cork-oaks). Temporary specialised emigrants earned from 3.5 francs to 4 francs a day and never stayed longer than three months. During the summer months 400 Italians went to work in the mines, in particular Sardinians from Iglesias who were renowned for their technical knowledge about minerals, which was often matched by their abilities in the construction of galleries and in the triage of minerals. ${ }^{50}$ They were the best paid specialised category of workers, earning from 5 francs to 9 francs a day (also given the fact that their type of job was particularly dangerous, fatiguing, and illness-prone). Unspecialised workers in the mines were often autochthonous and earned 30-40\% less than European workers according to Loh they also worked less because they were physically weaker. ${ }^{51}$ Emigration in this case brought investments and in 1904 Luigi Donegani, the founder of Montecatini (which was to become Italy's largest chemical firm) set up the Tunisian Phosphates Company and started the exploitation of Kallat Gerdah, the most important phosphate deposit in Tunisia. ${ }^{52}$

One of most interesting aspects of Sicilian emigration to Tunisia is that Sicilians increasingly became small land-owners. Indeed, as the Parliamentary inquiry on Southern farmers underlined: 'Sicilians are not so much attracted by higher salaries, but by the mirage of becoming land-owners, something that it would be crazy to hope for in their region where latifundia dominated. ${ }^{, 53}$ Likewise Coletti, a contemporary economist, also described Sicilian emigration to Tunisia as determined by 'special circumstances': not only the fact that it was close, easily accessible and with similar climatic and soil characteristics, but that there also existed the concrete possibility to become a small landowner. ${ }^{54}$ Or again, as one of the leading Italian newspapers of the time stated in 1900: 'The Sicilian immigrant has got one and only aim: buy a little piece of land to support his family even if it means to mortgage his future work for many years ahead. ${ }^{55}$

As a matter of fact, with the beginning of the French protectorate, the colonial government decided to sell the land which formerly belonged to the Bey, its ministers, the Caids (tribal chiefs), and their relatives and encourage private colonisation. Vast estates were sold to French investment companies, speculators, absentee owners, and large firms. ${ }^{56}$ French labour was never attracted and Tunisia was thus colonised by French capitalists who bought large estates in the fertile north and hired Italians because they worked for a lower wage than French nationals. ${ }^{57}$ Some of the French investors successively decided to sell the land. The Franco-African company sold 1 hectare per 150 lire and many Sicilians, who had arrived in Tunisia without any means but their working capacity, were able to save as much as they could in order to make their dream come true. Others took advantage of a traditional institution called enzel (or inzâl) which gave them the possibility to become a perpetual lease-holder of the land through the payment of a fixed rent. The French colonial government allowed them to buy from five to ten hectares against the payment of a sixteen-year rent, thus transforming the perpetual lease in a sales contract which released the land against a set amount of money. ${ }^{58}$ In the words of Foerster: 
The penniless immigrant begins as a hired man, earning 60 or 70 francs a month and saving half of it. In 3-4 years he lays by 1000 francs enough to begin the enzel arrangement. Paying commonly about 15 francs per hectare per year, he secures the right to hold and improve his land in perpetuity, passing the right on to his children. At any time, by making 16 payments, he may receive the full title of his land. In this way many Italians have already become proprietors or have advanced on the road to ownership. ${ }^{59}$

Besides the big French investment companies, a few rich Sicilian families also bought large land properties and became 'colonising enterprises'. Saporito and Nasi bought 2,700 hectares, while Salvatore Canino bought 4,400 hectares and then either resold smaller parcels to individual buyers, creating a vast group of small landowners, or rented out as inzâl small allotments of two to five hectares to farmers from Marsala and Trapani, offering them the concrete possibility to become de facto owners. In the areas of Tunisi and Grombalia 18,500 hectares were devoted to the cultivation of grapevines and produced 350,000 hectolitres of wine. The activity of these colonising Sicilian enterprises alarmed the French who devised 'an almost military method in the Italian colonisation plan agreed with the Italian government itself'. Despite a tradition of good enough relations with France, Italian migration and land acquisition fomented the psychosis of the 'invasion sicilienne' ${ }^{60}$

Sicilian emigration and interest in becoming a land-owner had started to increase after the Italo-French tariff war (1887) and the bankruptcy of many small wine producers who were predominantly selling on the French market, to which it must be added the grape phyloxera which destroyed a great part of the Sicilian vineyards at the turn of the century. ${ }^{61}$ In five years time, Italian land had almost doubled (Table 4), even though it amounted to just $6 \%$ of French land in Tunisia. Italians overtook the French only as small land-owners (up to ten hectares) in 1902: 537 against 437 French small owners. Sicilians were good and tireless farmers, cultivated grapes, and produced wine which sold well on the French market, so much so that after the First World War the price of one hectare of vineyard reached between 70,000 and 80,000 francs, 'an incredibly high price' according to contemporary observers. ${ }^{62}$ Italian land in Tunisia extended to 84,552 hectares by 1915 .

Since Italian emigration could endanger French influence, a series of anti-Italian and pro-French colonisation initiatives were introduced by the protectorate at the turn of century. Between 1896 and 1901 the colonial government forbade the Italian community from opening new schools, lawyers could not go into practice without a French degree, and Italian entrepreneurs were banned from taking part in publicworks competitions - while Italian labour in public service and French mines was to be paid one-third less than their French counterparts. Finally, an attempt was made to outlaw Italian doctors and pharmacists. ${ }^{63}$ Moreover, the French colonial government resolved to appoint only French companies to work in Tunisia and at least $20 \%$ of the labour force they employed had to be French. ${ }^{64}$ The colonial government

Table 4. Italian land properties in Tunisia.

\begin{tabular}{lccc}
\hline & 1897 & 1902 & 1915 \\
\hline Number of properties & 407 & 740 & 1,271 \\
Number of hectares & 19,523 & 36,469 & 84,552 \\
\hline
\end{tabular}

Source: G. Loth, Le Peuplement Italien en Tunisie \& en Algérie (Paris, 1905), 175-6. 
also established institutions to aid French colonists and started a campaign to bring more French citizens over to Tunisia; plans for low-cost farm homes were prepared, with price estimates around 2,300 francs. In 1907 a fund of 7.5 million francs was approved for encouraging colonisation. ${ }^{65}$ Another way of increasing the number of French nationals in Tunisia was by naturalisation; bureaucratic procedures were eased at the end of the century but the naturalisation programme was never very successful among Italian immigrants. By 1931, for the first time in the history of Tunisia, the French and Italian communities matched, reaching a total of 91,000 inhabitants.

As a matter of fact, after the First World War Italian immigration to Tunisia started to slow down. Many had repatriated at the outbreak of the war. Many chose the Americas by virtue of much higher salaries, and others preferred not to go back to Tunisia due to the relative saturation of the labour market, both in industry and in agriculture, where the land was just enough to support the first migrant family and its (numerous) descendants. However, for those who had already settled in Tunisia, even French observers had to admit that it was prosperity that characterised Italian colonial farming: a prosperity which had quickly increased on the solid basis of relentless work and good prices for wine. Sicilians were by far the major component of the Italian colony in Tunisia; they had turned into permanent inhabitants of Tunisia and would only 'shortly go back to Sicily on occasion of traditionally important religious feasts such as La Madonna di Trapani'. ${ }^{66}$

Finally, as to remittances, Loth calculates quite interestingly that on the basis of data furnished by French colonial post offices, between 1897 and 1902 5,203,617 francs were sent back to Italy. These remittances were looked badly upon by the colonial government since they represented 'millions taken from the economy of the protectorate', yet in the author's opinion this money could just be considered 'a sort of tax France had to pay as a compensation to Italy given the low cost of Sicilian labour'. ${ }^{67}$

\section{Conclusion}

Italy today is a rich industrialised country, but it must be recognised that it succeeded in spite of formidable obstacles: an increasing North-South divide, which by the first decade of the new century placed the North - by every economic measure - far ahead of the South, basically cut off from modernisation and industrialisation. Other major obstacles relate to Italy's lack of natural resources and prime materials as well as a limited availability of fertile and well-watered farmland. Much of the arable land was hilly or mountainous, or, even worse, swampy and malarial. The essence of the problem was that the demographic increase gave way to too many farmers on too little land. The problem, as we have seen, was partially solved through massive emigration of Italy's labour force, which abroad was more productively employed, earned more, and sent money back. Remittance inflows greatly helped those who stayed behind as well as Italy's balance of payments. ${ }^{68}$

Africa is a particularly interesting case as a destination for Italian migrants because it offered peculiar and unique advantages. First, it allowed them to escape the poverty trap, enabling even daily labourers, the poorest category of workers in Southern Italy, to leave. Geographically it was the closest opportunity offered to Sicilians (and Sardinians) as well as the cheapest one, given the very low cost of the trip - only three to four days' work - on small sailing boats. Second, salaries in Africa were higher than in Italy, as we have seen, but the wage gap was not always the main 
push factor. Tunisia allowed the mirage of landowning to come true, and many Sicilian daily labourers living by manual work were able to became small landowners. It was the land of opportunity for those agricultural labourers who had been constantly frustrated in their attempts to get a more equal land distribution in Southern Italy. Soon Tunisia saw the birth of many little Sicilies, with Italian settlements in the countryside resembling typical Sicilian villages to the point that 'the houses give the impression of having been detached from the Sicilian soil and placed intact on the

Tunisian land. ${ }^{69}$ The French protectorate's colonisation programme helped many Sicilians to became small landowners, yet when Italian properties and workers started soaring (between 1897 and 1915 Italian properties in Tunisia quadrupled from 19,523 to 84,552 hectares) and a Sicilian invasion seemed a reasonable fear, new pro-French-citizen colonial laws were introduced at the turn of the century. The Italian community in Tunisia reached 90,000 by 1927 , plus a commuting group of workers who disembarked at the beginning of the summer and were engaged in different tasks in agriculture, forestry, public works, and the mines.

The economic impact of these skilled Italian workers in Africa was undoubtedly important but difficult to assess in economic terms. What can be inferred from local historical studies is that they introduced new products and cultivation techniques in agriculture. Those who came to stay sent feeble remittances back, were well integrated in the local community ${ }^{70}$, and produced some kind of direct investment, as in the case of Sicilians who invested in the acquisition of land. But we should also remember the case of the Tunisian Phosphate Company founded by Donegani in 1904.

It also clearly emerges from this research that Italian emigration to North African countries was not connected with the colonial policy of European countries; it had started before the scramble for Africa began and it continued afterwards. French colonial accomplishments did not overthrow preferences and traditions that ancestrally linked the Italian and the North African communities throughout the history of the Mediterranean.

After the First World War Italian emigration to Africa slowed down, overseas opportunities cut off the feeble African flows, and with the onset of the Fascist regime (1922), emigration was progressively discouraged altogether (except towards the new colonial empire, albeit with very little success). ${ }^{71}$ After the Second World War Tunisia was still the African country hosting the largest number of Italians. However, the abolition of the foreign ownership of land by the Tunisian government in 1964 was the end of the Italian community in Tunisia, which split in half between Italy and France in going back to Europe. The Sicilians' dream of cultivating their own small piece of land inevitably crashed against the heavy burden of history.

\section{Notes}

1. A. Del Boca, Gli Italiani in Africa Orientale (Bari, 1997); A. Del Boca, Adua Le ragioni di una sconfitta (Bari, 1998); N. Labanca, In marcia verso Adua (Turin, 1993).

2. S. Speziale, Reti mediterranee e tesori d'Italia (Cosenza, 2011).

3. L. Cafagna, 'Discussion of the Origins of Italian Economic Dualism' and R.S. Eckaus, 'Italian Economic Development' reprinted in G. Federico, The Economic Development of Italy since 1870 (Cambridge, 1994). See also: V. Zamagni, Introduzione alla storia economica d'Italia (Bologna, 2007).

4. E. Felice, Divari regionali e intervento pubblico (Bologna, 2007), 123-33; E. Felice, 'Regional Value Added in Italy, 1891-2001 and the Foundation of a Long-Term Picture', The Economic History Review, 1xiv (2011), 929-50. 
5. S. Fenoaltea, The Reinterpretation of Italian Economic History: from Unification to the Great War (Cambridge, 2011), 211-30.

6. V. Zamagni, Industrializzazione e squilibri regionali in Italia (Bologna, 1978), 199.

7. Felice, 'Divari regionali', 137.

8. G. Toniolo, An Economic History of Liberal Italy 1850-1918 (London, 1990), 112.

9. R.A. Easterlin, 'Why Isn't the Whole World Developed?', Journal of Economic History, xli (1981); L. Sandberg, 'The Case of the Impoverished Sophisticate: Human Capital and Swedish Economic Growth before World War I', Journal of Economic History, xxxix (1979); G. Alter and G. Clark, 'The Demographic Transition and Human Capital' in S. Broadberry and K. O'Rourke, The Cambridge Economic History of Modern Europe (Cambridge, 2010).

10. V. Zamagni, The Economic History of Italy 1860-1990 (Oxford, 1993), 23-4.

11. P.K. O'Brien and G. Toniolo, 'The Poverty of Italy and the Backwardness of its Agriculture Before 1914' in G. Federico, The Economic Development of Italy since 1870 (Cambridge, 1994), 346-70.

12. J. Cohen and G. Federico, The Growth of the Italian Economy 1820-1960 (Cambridge, 2001), 109.

13. Toniolo, 'An Economic History', 4-5.

14. Zamagni, 'The Economic History', 199.

15. Toniolo, 'An Economic History', 33.

16. E. Sori, L'emigrazione Italiana dall'unità alla seconda Guerra mondiale (Bologna, 1979), 32 .

17. F. Fauri, Storia economica delle migrazioni italiane (Bologna, forthcoming).

18. Fenoaltea, 'The Reinterpretation', 152-65.

19. T.J. Hatton and J.G. Williamson (eds), Migration and the International Labor Market, 1850-1939 (London, 1994); T.J. Hatton, 'A Model of UK Emigration, 1870-1913', Review of Economics and Statistics, lxxvii (1995), 407-15.

20. A.M. Taylor and J. G. Williamson, 'Convergence in the Age of Mass Migration', European Review of Economic History, i (1997).

21. R. Easterlin, 'Regional Income Trends, 1840-1950' in S.E. Harris (ed), American Economic History (New York, 1961), 525-47; T. Hatton and J.G. Williamson, The Age of Mass Migration: Causes and Economic Impact (New York, 1998), 104.

22. Fauri, 'Storia economica delle migrazioni'.

23. M. Gomellini and C. Ó Gráda, 'Outward and Inward Migrations in Italy: A Historical Perspective', Banca d'Italia Quaderni di Storia Economica, viii (2011).

24. T.J. Hatton and J.G. Williamson, 'What Fundamental Drive World Migration?', CEPR Discussion Paper, mmmdlix (2002), 10. R. Faini and A. Venturini, 'Italian Emigration in the Pre-War Period' in Hatton and Williamson, Migration; E. Moretti, 'Migration and Social Network Italy 1889-1913', International Migration Review, xxxiii (1999), 640-57.

25. R.F. Foerster, The Italian Emigration of Our Times (New York, 1919), 214-5.

26. Ministero di agricoltura, industria e commercio (MAIC), Direzione della statistica generale, Statistica della emigrazione italiana all'estero nel 1881 (Rome, 1882), 50-2.

27. MAIC, Statistica della emigrazione italiana per l'estero con una appendice di confronti internazionali (Rome, 1913).

28. Foerster, 'The Italian Emigration', 212.

29. J. Foreman Peck, A History of the World Economy (New York, 1995), 131.

30. R.H. Rainero, 'Aspetti e vicende dell'emigrazione italiana in Algeria dalle origini all'avvento del fascismo' in R.H. Rainero (a cura di), Aspetti storici di un'amicizia mediterrane (Milan, 1982).

31. MAIC, 'Statistica della emigrazione italiana all'estero'.

32. D. Occhipinti, In Tunisia (Rome, 1939), 11.

33. M. Vernassa, 'Presenze toscane nella reggenza di Tunisi (1843-1851)' in V.A. Salvadorini (ed), In Tunisia e Toscana (Pisa, 2002), 434-6.

34. K.J. Perkins, A History of Modern Tunisia (Cambridge, 2004), 20.

35. E. De Leone, La Colonizzazione dell' Africa del Nord (Padua, 1957), 242.

36. Ibid., 277.

37. D. Melfa, Migrando a sud. Coloni italiani in Tunisia (1881-1939) (Rome, 2008), 72.

38. D.L. Ling, Tunisia From Protectorate to Republic (Bloomington, 1967), 25. 
39. Ibid., 26-7.

40. J. Ganiage, Les origines du protectorat français en Tunisie (1861-1881) (Paris, 1959).

41. The Rubattino purchase of the railroad from Tunis to La Goulette was a case in point: since its English owners had found this twenty miles of railway unprofitable, they had decided to sell it. The French Bone-Guelma Company and the Italian Rubattino Company opened negotiations, they both claimed victory but in the end the British High Court of Justice validated the Italian bid and despite French protests and attempts to intimidate the Bey, the line was sold to Rubattino. Ling, 'Tunisia'; J. Ferry, Discours sur la politique extérieure et coloniale. 2., Affaires tunisiennes (suite et fin), Congo, Madagascar, Égypte, Tonkin (Paris, 1897).

42. Occhipinti, 'In Tunisia', 54.

43. Perkins, 'A History', 44.

44. Foerster, 'The Italian Emigration', 214-5.

45. MAIC, 'Statistica dell'emigrazione italiana', 205-6.

46. A.E. Sayous, 'Les italiens en Tunisie', Revue Economique international, cxi (1957), 69-71;

J. Despois, La Tunisie (Paris, 1927), 84.

47. Russel, 'The Italian Community'.

48. Ministero degli Affari Esteri (MAE), Emigrazione e colonie, Tunisia (Rome, 1904), 334.

49. G. Loth, Le Peuplement Italien en Tunisie \& en Algérie (Paris, 1905), 141-4.

50. G. Barilotti, 'La comunità italiana in Tunisia: società lavoro e emigrazione. Il caso dei sardi' in G. Barilotti (ed), L'Italia e il Nord Africa (Florence, 2006), 128.

51. Loth, 'Le Peuplement Italien', 146.

52. E. Fadda Pasella, 'Studio geologico minerario sulla Tunisia', Rassegna Mineraria e Metallurgica italiana, lxix (1931).

53. Inchiesta Parlamentare sulle condizioni dei contadini nelle provincie meridionali e in Sicilia, VI Sicilia, Relazione del delegato tecnico G. Lorenzoni (Rome, 1911), 746.

54. F. Coletti, 'Dell'emigrazione italiana' in F. Brancato, L'emigrazione siciliana negli ultimi cento anni (Cosenza), 134.

55. Corriere della sera, 1900, n.231.

56. L. Anderson, The State and Social Transformation in Tunisia and Libya, 1830-1980 (Princeton, 1999).

57. Ling, 'Tunisia', 80.

58. M. Trombetta, Lezioni di geografia economica e emigrazione (Riposto, 1914), 66.

59. Foerster, 'The Italian Emigration', 216.

60. De Leone, 'Le Peuplement Italien', 346-50.

61. F. Fauri, L'integrazione prematura: le relazioni commerciali europee dalla metà dell'Ottocento alla Grande Guerra (Bologna, 2005).

62. E. Castellani, La Tunisia: agricoltura e colonizzazione (Florence, 1942), 47.

63. Occhipinti, 'In Tunisia', 65.

64. Comitato della Camera Italiana di Commercio ed Arti, Gli italiani in Tunisia (Tunis, 1913), 156-7.

65. Ling, 'Tunisia', 82.

66. Sayous, 'Les Italiens', 72-5.

67. Loth, 'Le Peuplement Italien', 163-4.

68. F. Balletta, Le rimesse degli emigranti italiani e la bilancia dei pagamenti internazionali 1861-1975 (Napoli, 1976), 270-5.

69. Sayous, 'Les italianes', 94-5.

70. Sicilians in Tunisia 'contaminated' their Catholicism with local religious traditions while many Arabic words and expressions were completely assimilated in their dialect. See: L. El Houssi, 'Italians in Tunisia: between Regional Organisation, Cultural Adaptation and Political Division 1860s-1940', European Review of History, xix (2012), 168.

71. D. Strangio, Da colonie a paesi in via di sviluppo. L'evoluzione dei sistemi economici dalla colonizzazione alla globalizzazione (Milan, 2011). 